\title{
Impacts of land-use and management systems on organic carbon and water-physical properties of a Latossolo Amarelo (Oxisol) ${ }^{1}$
}

\author{
Impactos de sistemas de uso e manejo no carbono orgânico e \\ atributos físico-hídricos de um Latossolo Amarelo
}

\author{
Rodrigo Fonseca da Silva ${ }^{2 *}$; Glenio Guimarães Santos ${ }^{3}$; \\ Júlio César Azevedo Nóbrega ${ }^{4}$; Geraldo César de Oliveira ${ }^{5}$; \\ Bruno de Oliveira Dias ${ }^{6}$; Djavan Pinheiro Santos ${ }^{7}$; Juvenal Pereira da Silva Júnior ${ }^{8}$
}

\begin{abstract}
The Cerrado biome has outstanding territorial relevance in the state of Piauí, in which weather conditions, relief and favorable soil has made this region one reference in food production. This study focused to evaluate the effects of different land uses, management systems and their respective terms on organic carbon content and physical properties of a Latossolo Amarelo (Oxisol) in the Southwestern Piauí state. The study was performed in the city of Uruçuí, situated in the southwestern Piauí state. We assessed nine farming areas with different backgrounds regarding land-use, management system and run time. The treatments consisted of areas under no-till for 3 and 6 years (NT3 and NT6), under pasture for 2 and 5 years (PA2 and PA6), under eucalyptus plantation for six and twelve years (EU6 and EU12), under conventional tillage for two and 8 years (CT2 and CT8) and under native Cerrado (NC), which represented a reference condition. Conversion of the native Cerrado into no-till and grazing areas increased soil organic carbon content over time.
\end{abstract}

Key words: Eucalyptus. Conventional planting. Grazing. Tillage. Soil water.

\section{Resumo}

O bioma Cerrado tem notável relevância territorial no estado do Piauí, e devido as suas características de clima, relevo e solos favoráveis tem tornado essa região uma referência na produção de alimentos no estado. A partir desse estudo se objetivou avaliar as implicações dos diferentes sistemas de uso, manejo e tempo de adoção nos teores de carbono orgânico e em atributos físicos do solo em um Latossolo Amarelo da região Sudoeste do estado do Piauí. O estudo foi realizado no município de Uruçuí, locado na região sudoeste do estado do Piauí. Neste estudo foram avaliados nove sistemas de produção com diferentes históricos de uso, manejo e tempo de adoção disposto da seguinte forma: áreas sob sistema de plantio direto (PD3 e PD9, respectivamente com três e nove anos de cultivo), áreas sob pastagem (PA2 e PA6, respectivamente com dois e seis anos de cultivo), áreas sob plantio de eucalipto (EU6 e EU12, respectivamente com seis e doze anos de cultivo), áreas sob sistema de preparo convencional

${ }^{1}$ Parte da Dissertação de Mestrado do primeiro autor, apresentada a Universidade Federal do Piauí, UFPI.

2 Discente de Doutorado em Ciência do Solo, Universidade Federal de Lavras, UFLA, Lavras, MG, Brasil. E-mail: rodrigo11.07@ hotmail.com

3 Prof., Universidade Federal de Goiás, Goiânia, UFG, GO, Brasil. E-mail: gleniogm@gmail.com

${ }^{4}$ Prof., Universidade Federal do Recôncavo da Bahia, UFRB, Cruz das Almas, BA, Brasil. E-mail: jcanobrega@ufrb.edu.br

5 Prof., Universidade Federal de Lavras, UFLA, Lavras, MG, Brasil. E-mail: geraldooliveira@dcs.ufla.br

${ }^{6}$ Prof., Universidade Federal da Paraíba, UFPB, Areia, PB, Brasil. E-mail: b2dias@yahoo.com.br

7 Discente de Doutorado em Agronomia, UFG, Goiânia, GO, Brasil. E-mail: djavansantos@hotmail.com.br

${ }^{8}$ Discente de mestrado, Universidade Federal do Piauí, UFPI, Bom Jesus, PI, Brasil. E-mail: juvenal_junior@hotmail.com

* Author for correspondence 
(PC2 e PC8, respectivamente com dois e oito anos de cultivo) e Cerrado nativo (CN), representando uma condição de referência. A conversão do Cerrado nativo em plantio direto e pastagem ocasionou evolução no conteúdo de carbono orgânico com o passar do tempo.

Palavras-chave: Água no solo. Alteração estrutural. Eucalipto. Pastagem. Plantio convencional. Plantio direto.

\section{Introduction}

The Cerrado biome covers $46 \%$ of the Piauí state area which corresponds to approximately 11.8 million hectares (AGUIAR; MONTEIRO, 2005). Given the climate, relief and favorable soil properties for food production, it is expected a large increase in local population purchasing power with the advancement of agriculture in this region, thereby improving the Human Development Index (HDI) of this state, which is considered one of the lowest in Brazil (IBGE, 2013).

During the 2013/14 crop season, areas grown with soybeans, corn and rice reached respectively 630, 404 and 177 thousand hectares within this state. It corresponds to an increase of 15, 7 and $6 \%$ of the cropped area compared to the previous harvest (CONAB, 2014). Moreover, according to an agricultural census (IBGE, 2006), the areas cultivated with annual/ permanent crops, planted forest/ pasture increased by about 220\%, 173\%, $618 \%$ and $454 \%$ respectively, from 1970 until 2006. These data highlight the growing expansion of farming and forestry sectors in this part of the country. Meanwhile, it becomes necessary to point out concerns of technicians and researches on the inappropriate use of natural resources in this region (SILVA et al., 2015b). Thus, without using an appropriate soil management, environmental negative consequences might arise within a medium to long-term, reflecting in crop yield losses (SILVA et al., 2011).

In studies on suitable techniques for cropland use and management, several Brazilian authors have suggested as soil quality indicators a large number of physical and mechanical properties as aeration, water storage capacity and penetration resistance (PR) (OLIVEIRA et al., 2004; ARAÚJO et al., 2007; SEVERIANO et al., 2011; LIMA et al., 2012; SERAFIM et al., 2013; SILVA et al., 2015a). These properties are chosen for being sensitive to impacts against soil (MENDES et al., 2006; PRAGANA et al., 2012; SILVA et al., 2015a). Thus, the least limiting water range appears as an auxiliary tool for soil hydro-physical quality assessment (GUIMARAES et al., 2013), once it relates soil density to critical aeration intensity, water potentials as well as soil resistance to penetration (LETEY, 1985; SILVA et al., 1994), serving as a subsidy to compare land uses and managements.

Accordingly, a few factors such as ongoing soil disturbance, intensive agricultural mechanization (BERTOL et al., 2004), crop harvest, deforestation (DIAS JUNIOR et al., 2005) and cattle trampling (FIGUEIREDO et al., 2009) can provide intense compaction, reducing macroporosity and increasing PR. Thus, these factors may affect least limiting water range (TORMENA et al., 2007; GUIMARAES et al., 2013), besides changing soil organic carbon content (MACHADO et al., 2014).

Hence, this study aimed to evaluate the impacts caused by different land uses, management systems and respective terms on water-physical properties and organic carbon content in a Latossolo Amarelo Distrófico típico caulinítico (Oxisol) from Piauí state Cerrado area.

\section{Material and Methods}

\section{Area description}

The study area is located in Nova Santa Rosa, Uruçuí district (at geographical coordinates of $7^{\circ}$ 14 ' 2" south latitude, $44^{\circ} 33^{\prime} 14$ " west longitude) in Western Piauí state (Figure 1). In the study area, the dominant soils are Latossolos Amarelos Distróficos 
típicos cauliníticos (Oxisols) (PRAGANA et al., 2012). According to the Köppen's classification, local climate is tropical ( $A w$ type), which is characterized by hot and humid weather and average rainfall of $1,100 \mathrm{~mm} \mathrm{yr}^{-1}$, and temperature of $29^{\circ} \mathrm{C}$ (SOUSA et al., 2013).

Figure 1. Location of the study areas in the district of Nova Santa Rosa, Uruçuí, state of Piauí (PI). Soil management: native Cerrado (NC); eucalyptus plantation of six years (EU6); eucalyptus plantation of twelve years (EU12); pasture of two years (PA2); pasture of six years (PA6); conventional tillage of two years (CT2); conventional tillage of eight years (CT8), no-till of three years (NT3), no-till of six years (NT6).

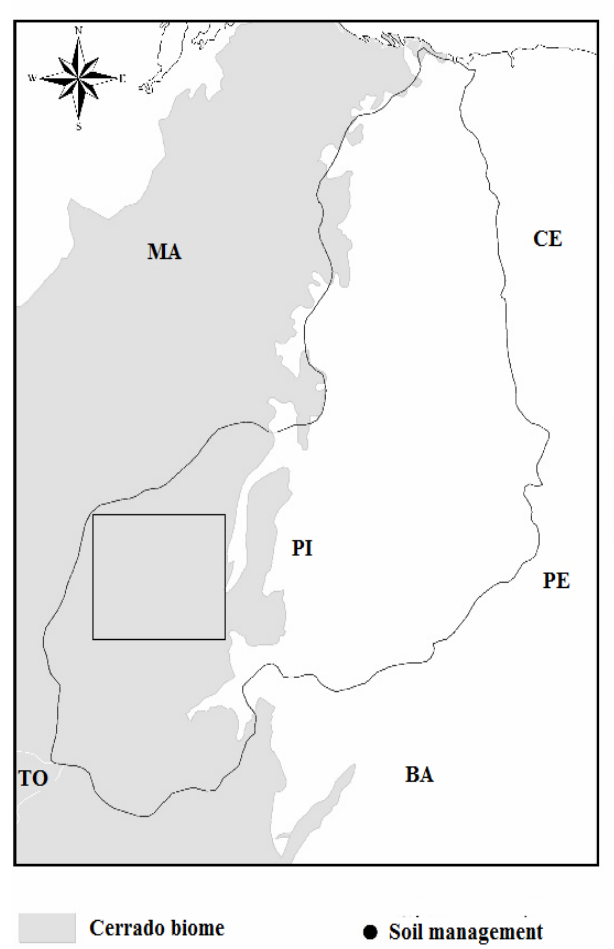

Soil sampling and treatments

We assessed nine farming areas with distinct backgrounds concerning land-use, management system and run time. These areas were divided in notill for 3 and 9 years (NT3 and NT9), pasture for 2 and 5 years (PA2 and PA6), eucalyptus plantation for six and twelve years (EU6 and EU12), conventional tillage for two and 8 years (CT2 and CT8) and under native Cerrado (NC), which represented a reference condition (Table 1).
For soil sampling, we set a one-ha central area with the aid of a GPS device and a metric tape. From this area, twenty-five points were established at a $25 \mathrm{~m}$ distance from each other. Subsequently, four of these points were chosen randomly, making the four replications, in which were taken samples at depth ranges of $0-0.10 ; 0.10-0.20 ; 0.20-0.30$ and 0.30-0.40 m. In native Cerrado areas, a $15-\mathrm{m}$ border was set from the edge of the legal reserve to further pursuit of the above-mentioned procedure. 
Table 1. History of use of a dystrophic Latossolo Amarelo Distrófico típico caulinítico (Oxisol) from a Cerrado area within Piauí state, after several years of adoption of different land uses and soil management systems.

\begin{tabular}{|c|c|}
\hline Treatment & Detailing of the land uses and managements, number of years and location of each area \\
\hline $\mathrm{NC}$ & $\begin{array}{l}\text { Native Cerrado with no history of human disturbance, in terms of agricultural use. Geographical } \\
\text { coordinates: } 08^{\circ} 17^{\prime} 10.8^{\prime \prime} \text { S. } 44^{\circ} 33^{\prime} 59.4^{\prime \prime} \mathrm{W} \text { and altitude of } 569 \mathrm{~m} \text {. }\end{array}$ \\
\hline EU 6 & $\begin{array}{l}\text { Native Cerrado deforested in the } 2007 / 2008 \text { crop season, being limed with } 5,000 \mathrm{~kg} \mathrm{ha}^{-1} \text { dolomitic } \\
\text { limestone. The area was grown with rice in the first year, applying } 35 \mathrm{~kg} \mathrm{~h}^{-1} \mathrm{P}_{2} \mathrm{O}_{5} \text { and } 18 \mathrm{~kg} \mathrm{ha}^{-1} \mathrm{~K}_{2} \mathrm{O} \text { in } \\
\text { planting row. In the following years, eucalyptus was planted without extra fertilizations. Geographical } \\
\text { coordinates: } 08^{\circ} 17^{\prime} 27.7^{\prime} \mathrm{S} \text {. } 44^{\circ} 39^{\prime} 55.4^{\prime} \mathrm{W} \text { and altitude of } 578 \mathrm{~m} \text {. }\end{array}$ \\
\hline EU 12 & $\begin{array}{l}\text { Native Cerrado deforested in the } 2000 / 2001 \text { season, being limed with } 4,000 \mathrm{~kg} \mathrm{ha}^{-1} \text { dolomitic limestone. } \\
\text { The area was grown with rice in the first year, applying } 35 \mathrm{~kg} \mathrm{ha}^{-1} \mathrm{P}_{2} \mathrm{O}_{5} \text { and } 18 \mathrm{~kg} \mathrm{ha}^{-1} \mathrm{~K}_{2} \mathrm{O} \text { in planting row. } \\
\text { In the following years, eucalyptus was planted without extra fertilizations. Geographical coordinates: } 08^{\circ} \\
15^{\prime} 50.3^{\prime \prime} \mathrm{S} .44^{\circ} 39^{\prime} 16.3^{\prime \prime} \mathrm{W} \text { and altitude of } 580 \mathrm{~m} \text {. }\end{array}$ \\
\hline PA 2 & $\begin{array}{l}\text { Area converted into farming system in the crop year of } 2001 / 2002 \text {, with liming throughout the years of } \\
2003,2005,2010 \text { and } 2012 \text {, using } 2,000 \mathrm{~kg} \mathrm{ha}^{-1} \text { dolomitic limestone. The area was grown with rice in the } \\
\text { first two years and then with soybeans. In the crop seasons of } 2009 / 2010 \text { and } 2010 / 2011 \text {, corn was cropped. } \\
\text { In the last two years, pastures of Urochloa brizantha were inserted, and since } 2009 \text { soil was not tilled. } \\
\text { Average fertilization was of } 100 \text { and } 80 \mathrm{~kg} \mathrm{ha}^{-1} \mathrm{P}_{2} \mathrm{O}_{5} \text { and } \mathrm{K}_{2} \mathrm{O} \text {, respectively, for both soybean and corn } \\
\text { crops, however, adding } 120 \mathrm{~kg} \mathrm{ha}^{-1} \mathrm{~N} \text { during corn cultivation. Geographical coordinates: } 08^{\circ} 28^{\prime} 32.6^{\prime} \mathrm{S} \text {. } \\
44^{\circ} 57^{\prime} 82^{\prime \prime} \mathrm{W} \text { and altitude of } 550 \mathrm{~m} \text {. }\end{array}$ \\
\hline PA 6 & $\begin{array}{l}\text { Area converted into farming system in the crop year of } 2000 / 2001 \text {, initial soil tillage using } 4,000 \mathrm{~kg} \mathrm{ha}^{-1} \\
\text { dolomitic limestone and } 2,000 \mathrm{~kg} \mathrm{ha}^{-1} \text { in the years of } 2003,2006 \text { and } 2010 \text {. The area was grown with rice } \\
\text { in the first two years, soybeans in the following ones. In the last six years, grazing areas with Urochloa } \\
\text { brizantha was inserted. Average fertilization applied in the planting rows was of } 100 \mathrm{~kg} \text { ha }^{-1} \mathrm{P}_{2} \mathrm{O}_{5} \text { and } 80 \\
\mathrm{~kg} \mathrm{ha}^{-1} \mathrm{~K}_{2} \mathrm{O} \text { for soybean crop. Geographical coordinates: } 08^{\circ} 17^{\prime} 26.8^{\prime \prime} \mathrm{S} .44^{\circ} 35^{\prime} 03^{\prime \prime} \mathrm{W} \text { and altitude of } \\
553 \mathrm{~m} \text {. }\end{array}$ \\
\hline $\mathrm{CT} 2$ & $\begin{array}{l}\text { Area under conventional tillage - rice monocrop in the } 2011 / 2012 \text { season applying } 35 \mathrm{~kg} \mathrm{ha}^{-1} \mathrm{P}_{2} \mathrm{O}_{5} \text { and } \\
18 \mathrm{~kg} \mathrm{ha}^{-1} \mathrm{~K}_{2} \mathrm{O} \text { in the planting row, without dolomitic limestone use. In the } 2012 / 2013 \mathrm{crop}^{-1} \text { season, the } \\
\text { area was limed with } 5,000 \mathrm{~kg} \mathrm{ha}{ }^{-1} \text { limestone and soybeans fertilized with } 130 \mathrm{~kg} \mathrm{ha}^{-1} \mathrm{P}_{2} \mathrm{O}_{5} \text { and } 95 \mathrm{~kg} \mathrm{ha}^{-1} \\
\mathrm{~K}_{2} \mathrm{O} \text { in the planting row. Geographical coordinates: } 08^{\circ} 12^{\prime} 25^{\prime \prime} \mathrm{S} \text {. } 44^{\circ} 34^{\prime} 35.3^{\prime \prime} \mathrm{W} \text { and altitude of } 500 \mathrm{~m}^{-}\end{array}$ \\
\hline PC 8 & $\begin{array}{l}\text { Native Cerrado deforested in the } 2006 / 2007 \text { crop season, being afterwards cropped under conventional } \\
\text { tillage with intensive tilling, being previously limed using } 5,000 \mathrm{~kg}^{-1} \text { dolomitic limestone, and a further } \\
\text { application of } 2,000 \mathrm{~kg} \mathrm{ha}^{-1} \text { of the same product in } 2009 \text { and in } 2012 \text {. Area under soybean monocrop over } \\
\text { almost all years, except in } 2012 / 2013 \text { season, when corn was grown. Average fertilization applied in the } \\
\text { planting rows was of } 100 \mathrm{~kg} \mathrm{ha}^{-1} \mathrm{P}_{2} \mathrm{O}_{5} \text { and } 120 \mathrm{~kg} \mathrm{~h}^{-1} \mathrm{~K}_{2} \mathrm{O} \text { in all soybean crop seasons, adding } 130 \mathrm{~kg} \mathrm{~h}^{-1} \\
\mathrm{~N} \text { in the corn cultivation year. Geographical coordinates: } 08^{\circ} 17^{\prime} 49.7^{\prime \prime} \mathrm{S} .44^{\circ} 29^{\prime} 47.9^{\prime} \mathrm{W} \text { and altitude of } \\
572 \mathrm{~m} \text {. }\end{array}$ \\
\hline PD 3 & $\begin{array}{l}\text { Area converted into farming in } 1999 / 2000 \text {, with initial application, and every three years of } 5,000 \text { and } \\
2,000 \mathrm{~kg} \mathrm{ha}^{-1} \text { limestone, respectively. In the first crop year, the area was grown with rice and then with } \\
\text { soybeans, using millet as second crop or mulching in most years of cultivation by } 2008 / 2009 \text {. In the } 2009 / \\
2010 \text { season, a no-till system was adopted (NTS) using millet for straw interspersing crops of corn and } \\
\text { soybeans until the crop year of } 2012 / 2013 \text {, with average fertilization using } 100 \text { and } 120 \mathrm{~kg} \mathrm{ha}^{-1} \mathrm{P}_{2} \mathrm{O}_{5} \text { and } \\
\mathrm{K}_{2} \mathrm{O} \text {, respectively, adding } 130 \mathrm{~kg} \mathrm{ha}^{-1} \mathrm{P}_{2} \mathrm{O}_{5} \mathrm{~N}_{2} \text { for corn crops. Geographical coordinates: } 08^{\circ} 18^{\prime} 16^{\prime} \text { ' S. } 44^{\circ} \\
35^{\prime} 17^{\prime} \text { W and altitude of } 572 \mathrm{~m} \text {. }\end{array}$ \\
\hline PD 6 & $\begin{array}{l}\text { Area converted into farming in } 2002 / 2003 \text {, being deforested and cultivated under a conventional tillage } \\
\text { system, previously limed with } 5 \text { tons ha- of dolomitic limestone. In the following years, } 2 \text { tons ha }{ }^{-1} \text { of } \\
\text { limestone were applied every } 3 \text { years. It was grown with rice in the first crop year. In the following years, } \\
\text { it was cropped with soybeans up to the growing season of } 2006 / 2007 \text {. From the seasons of } 2007 / 2008 \text { up } \\
\text { to } 2012 / 2013 \text {, three corn crops were interspersed with soybeans. In } 2007 / 2008 \text {, no-till system was adopted } \\
\text { using millet for straw. Average fertilization was performed using } 100 \mathrm{~kg} \mathrm{ha}^{-1} \mathrm{P}_{2} \mathrm{O}_{5} \text { and } 120 \mathrm{~kg} \mathrm{ha}^{-1} \mathrm{~K}_{2} \mathrm{O} \\
\text { for all crop seasons of soybeans and corn, adding } 130 \mathrm{~kg} \mathrm{~h}^{-1} \mathrm{~N} \text { during corn cultivation. Geographical } \\
\text { coordinates: } 08^{\circ} 30^{\prime} 68.1^{\prime \prime} \mathrm{S} .44^{\circ} 58^{\prime} 81.1^{\prime \prime} \mathrm{W} \text { and altitude of } 572 \mathrm{~m} \text {. }\end{array}$ \\
\hline
\end{tabular}


Analyses: soil organic carbon (OC), sulfuric acid digestion and particle size

Both particle size and OC analyses were made in 144 disturbed soil samples taken at the four depth ranges from the nine assessed areas with four replications each. Soil particle size was determined by the pipette method (DONAGEMA et al., 2011), and the fractions were classified according to the system adopted by the Brazilian Society of Soil Science (EMBRAPA, 2013).

The organic carbon content was determined by automated dry combustion using an organic carbon analyzer (Vario TOC Cube model, Elementar). To this end, two milligrams of undisturbed soil samples were weighed for each study condition (144 samples) by means of an analytical balance with an accuracy of $0.00001 \mathrm{~g}$. Then, these samples were ground in a mortar, sieved $(0.250 \mathrm{~mm}$ mesh $)$ and dried at $65^{\circ} \mathrm{C}$ for $48 \mathrm{~h}$ for moisture removal. Samples were then wrapped and sealed in tin capsules to be incinerated at $950{ }^{\circ} \mathrm{C}$ for $5 \mathrm{~min}$. After combustion, all the organic matter was converted into carbon dioxide $\left(\mathrm{CO}_{2}\right)$ and an infrared sensor detected the amount of $\mathrm{CO}_{2}$ generated. This gas amount was automatically converted into elemental $\mathrm{C}$ concentrations.

Silica $\left(\mathrm{SiO}_{2}\right)$, aluminum oxide $\left(\mathrm{Al}_{2} \mathrm{O}_{3}\right)$, iron $\left(\mathrm{Fe}_{2} \mathrm{O}_{3}\right)$ and titanium $\left(\mathrm{TiO}_{2}\right)$ were extracted via sulfuric acid digestion as in Resende et al. (1987), solely in soil samples from native Cerrado (16 samples). $\mathrm{Ki}$ and $\mathrm{Kr}$ molecular relationships were calculated according to IBGE (2007) (Table 2). Thus, soil was classified as kaolinitic $(\mathrm{K}>0.75, \mathrm{Kr}>$ 0.75 ), and medium texture (clay content between 150 and $350 \mathrm{~g} \mathrm{~kg}^{-1}$ ) (EMBRAPA, 2013).

Table 2. Physical properties of a dystrophic Latossolo Amarelo Distrófico típico caulinítico under the different land management systems.

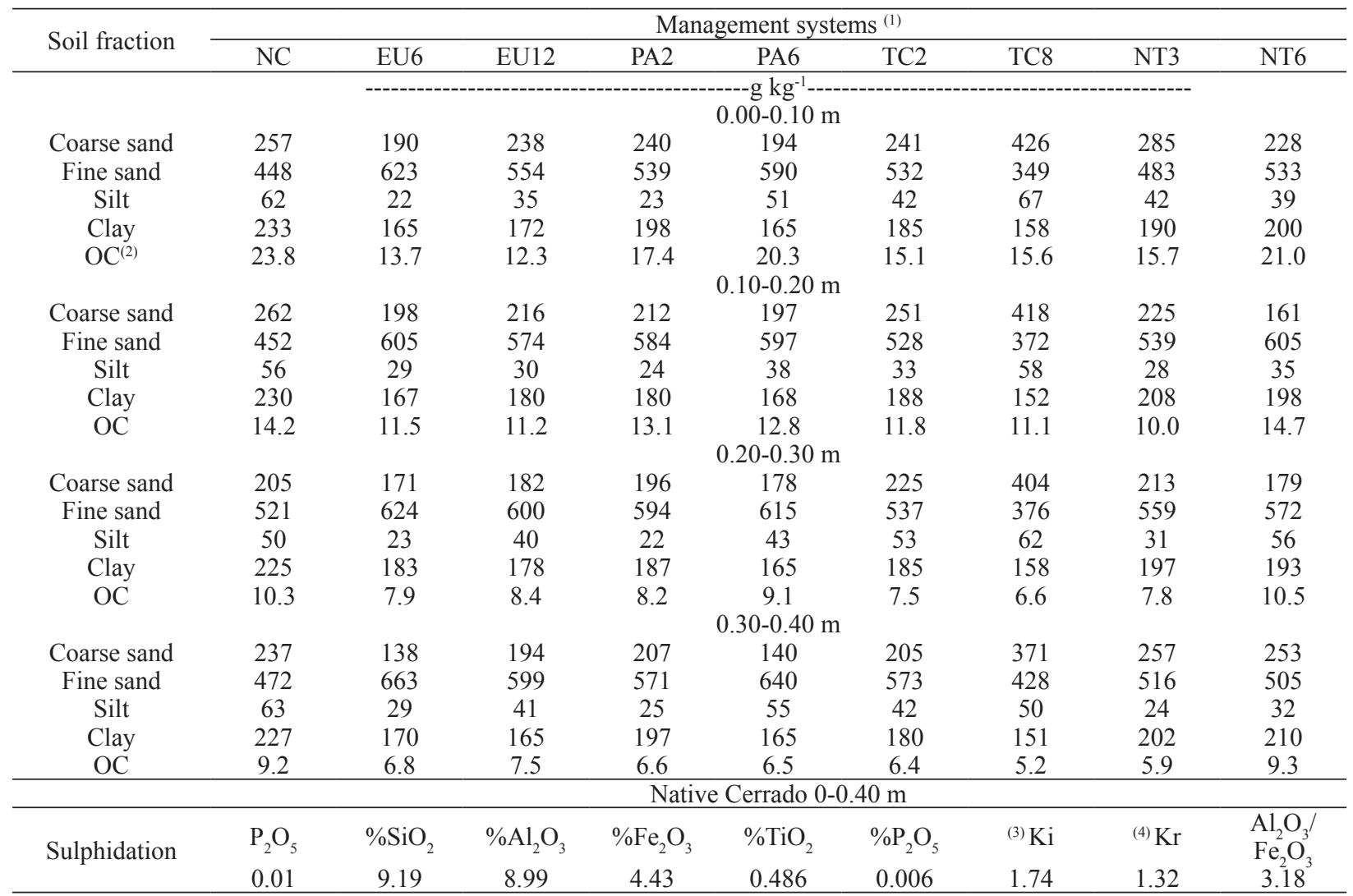

(1) Soil managements: native Cerrado (NC); eucalyptus plantation of six years (EU6); eucalyptus plantation of twelve years (EU12); pasture of two years (PA2); pasture of six years (PA6); conventional tillage of two years (CT2); conventional tillage of eight years (CT8), no-till of three years (NT3), no-till of six years (NT6). ${ }^{(2)}$ Organic carbon. ${ }^{(3)} \mathrm{Ki}: \mathrm{SiO}_{2} / \mathrm{Al}_{2} \mathrm{O}_{3}$ molecular ratio. ${ }^{(4)} \mathrm{Kr}$ : $\mathrm{SiO} 2 /\left({ }_{\mathrm{Al} 2 \mathrm{O}}\right.$ $+\mathrm{Fe}_{2} \mathrm{O}_{3}$ ) molecular ratio.. 
Soil bulk density, porosity and least limiting water range (LLWR)

Soil samples with preserved structure were used for determining density/ porosity of the soil and LLWR. These samples were collected from four mini-trenches dug per area (repetitions) for each management system and land use. The collection of samples was performed on soil core (with an approximate volume of $100 \mathrm{~cm}^{3}$ ), and then saturated by capillarity from the base.

A retention curve was built by testing eight matrix potentials of thirty-two samples taken from each situation. These matrix potentials were -2 , $-4,-6$ and $-10 \mathrm{kPa}$, for a tension table; and -33 , $-100,-500$ and $-1500 \mathrm{kPa}$, for Richards' extractors, according Donagema et al. (2011). After reaching water balance, the samples were weighed for further determination of soil resistance to penetration as proposed by Tormena etal. (1998). Then, the samples were dried at $\pm 105^{\circ} \mathrm{C}$ for $24 \mathrm{~h}$ for measurements of bulk density $(\mathrm{Bd})$ and water volumetric content of the soil $(\Theta)$ at the various tested tensions. The value $\Theta(-6 \mathrm{kPa})$ was used to estimate microporosity - MiP (DONAGEMA et al., 2011). The total pore volume (TP) was obtained according to equation 1 (Eq. 1) and particle density (Dp) according to Donagema et al. (2011). Macroporosity (MaP) was calculated from the difference between TP and MiP (DONAGEMA et al., 2011).

$$
\mathrm{TP}=1-\frac{\mathrm{Bd}}{D p}
$$

The force required to penetrate soil (kgf) was measured by a digital penetrographer (Marconi model MA 933) consisted of a metal rod with a $45^{\circ}$ half-angle and $0.1256 \mathrm{~cm}$ diameter at a constant speed of $0.01 \mathrm{~m} \mathrm{~min}^{-1}$. The measured force values, in $\mathrm{kgf}$, were thereafter converted to penetration resistance (PR) in MPa, considering the rod area, according to equations 2, 3 and 4 (Eq. 2, Eq. 3 and Eq. 4 ), which were adapted from Serafim et al. (2013):

$$
\begin{aligned}
& \mathrm{PR}=\frac{\mathrm{Fg}}{\left[\frac{\pi r^{2}}{\cos \left(45^{\circ}\right)}\right]} \frac{1}{10^{6}} \\
& P R=\frac{9.806648 F}{\left[\frac{3.1415926 \times 0.00192^{2}}{0.7071}\right]} \frac{1}{10^{6}} \quad \text { Eq. } 3 \\
& \mathrm{PR}=0.598755 \mathrm{~F} \\
& \text { Eq. } 4
\end{aligned}
$$

In which: PR is the soil penetration resistance to roots, in $\mathrm{MPa}$; $\mathrm{F}$ is the resistance value provided by the equipment, in kgf; $g$ is the gravity $(9.806648$ $\left.\mathrm{m} \mathrm{s}^{-2}\right) ; \pi$ is a dimensionless value (3.1415926); $\mathrm{r}$ is the rod radius $(0.00192 \mathrm{~m})$; and $\cos \left(45^{\circ}\right)$ is the cone surface cosine angle, which is equivalent to 0.7071 .

The LLWR was obtained through integration of effects of soil bulk density (Bd), penetration resistance (PR), water content $(\Theta)$ and water potential $(\psi)$, aiming to estimate the ideal water content in soil under varied land-use, managements during different terms in a Latossolo Amarelo Distrófico típico caulinítico (Oxisol).

Curves of water retention (WRC) and soil resistance to penetration (PRC) were adjusted to establish the LLWR. The curves were fitted at two situations. First, both WRC and PRC were adjusted to the soil in a general role, without considering the management systems and evaluated depth. Second, each management system and depth range individually adjusted both curves.

For WRC, the functional relationship between $\Theta$ and $\psi$ was incorporated with the effect of $\mathrm{Bd}$; thus, in this case, it was used the model proposed by Leão et al. (2006) (Eq. 5). In the case of PRC, the functional relationship between PR and $\Theta$ was incorporated with the effect of $\mathrm{Bd}$ to a non-linear model, being adjusted according model described by Silva et al. (1994) (Eq. 6). 


$$
\Theta=\operatorname{Exp}(a+b B d) \Psi^{c}
$$

$$
\mathrm{PR}=\mathrm{d} \Theta^{e} \mathrm{Bd}^{\mathrm{f}}
$$

Eq. 5

Eq. 6
If $\Theta_{\mathrm{AW}} \geq \Theta_{\mathrm{FC}}$ and $\Theta_{\mathrm{PR}} \geq \Theta_{\mathrm{PWP}} \therefore$ LLWR $=\Theta_{\mathrm{FC}}-\Theta_{\mathrm{PR}}$;

If $\Theta_{\mathrm{AW}} \leq \Theta_{\mathrm{FC}}$ and $\Theta_{\mathrm{PR}} \leq \Theta_{\mathrm{PWP}} \therefore$ LLWR $=\Theta_{\mathrm{AW}}-$ $\Theta_{\text {PWP }}$;

If $\Theta_{\mathrm{AW}} \leq \Theta_{\mathrm{FC}}$ and $\Theta_{\mathrm{PR}} \geq \Theta_{\mathrm{PWP}} \therefore$ LLWR $=\Theta_{\mathrm{AW}}-\Theta_{\mathrm{PR}}$.

\section{Statistics}

The data concerning soil bulk density, macroporosity, microporosity and total porosity were submitted to a descriptive analysis for observing specific traits of each management system and land use type. We also used the Pearson's correlation to understand the relationship between physical water parameters and soil organic carbon content. The Bd ranges at the different soil management systems were grouped into a single LLWR. For this purpose, we estimated the confidence interval (CI) within a random sample of 128 units, $\mathrm{t}_{\mathrm{n}-1}$ g.1.; $\alpha / 2$, wherein $n$ is the sample size; $\alpha$ is the significance level; and CI was given by $\mathrm{y} \pm \mathrm{t} \alpha$. The adjustments of WRC and PRC equations, as well as other statistical analyzes were performed using the $\mathrm{R}$ software version 3.2.3 (RDCT, 2015).

Afterwards, the LLWR of each management system and sampled depth was set based on $\Theta_{\mathrm{FC}}$, $\Theta_{\text {PWP }}, \Theta_{\text {AW }}$ and $\Theta_{\text {PR }}$. In order to choose $\Theta$ values for LLWR calculations, we adopted the method proposed by Silva et al. (1994), in which the following situations are found:

If $\Theta_{\mathrm{AW}} \geq \Theta_{\mathrm{FC}}$ and $\Theta_{\mathrm{PR}} \leq \Theta_{\mathrm{PWP}} \therefore$ LLWR $=\Theta_{\mathrm{FC}}-\Theta_{\mathrm{PWP}}$;

\section{Results and Discussion}

The various management systems and land use types had variations in $\mathrm{Bd}, \mathrm{TP}, \mathrm{MaP}$ and MiP, for all evaluated depths (Table 3). These results are consistent with those obtained by Oliveira et al. (2004), who evaluated soil bulk density and porosity. 
Table 3. Mean values of physical properties (soil bulk density, macroporosity, microporosity and total porosity), obtained in the different land uses and management systems in various soil depth ranges.

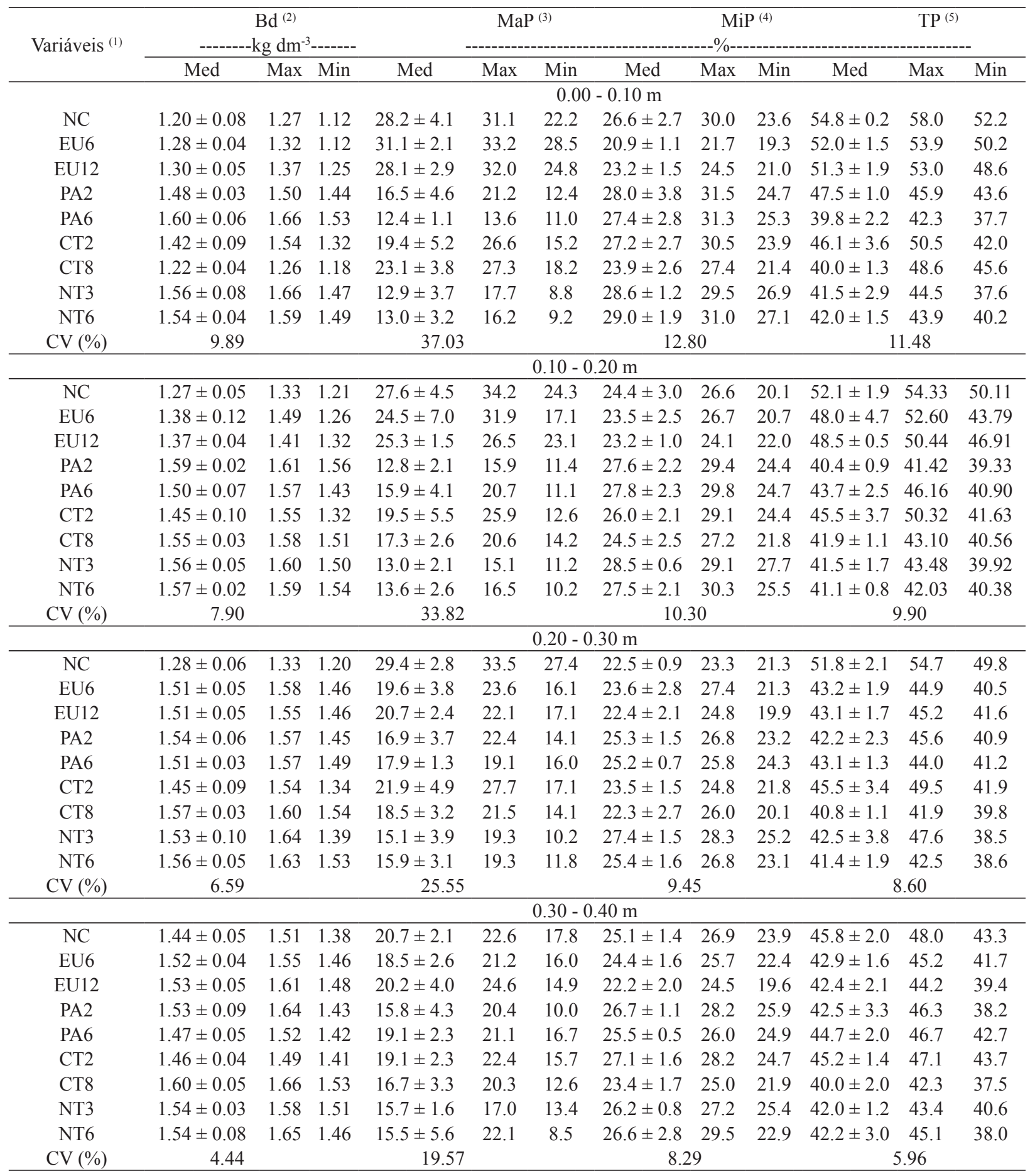

(1) Soil managements: native Cerrado (NC); eucalyptus plantation of six years (EU6); eucalyptus plantation of twelve years (EU12); pasture of two years (PA2); pasture of six years (PA6); conventional tillage of two years (CT2); conventional tillage of eight years (CT8), no-till of three years (NT3), no-till of six years (NT6). ${ }^{(2)}$ soil bulk density (Bd). ${ }^{(3)}$ macroporosity (MaP). ${ }^{(4)}$ microporosity (MiP), ). ${ }^{(5)}$ total porosity (TP). 
Taking native Cerrado area as reference, we observed major changes in soil density within 0-0.10 m depth under pasture and no-till systems. Meanwhile, there was no difference between $\mathrm{Bd}$ values for NT3 and NT6, which shows that when soil is not inverted, this parameter remains constant. This may be due to soil compaction throughout the first three years that reaches a steady state between pressure exerted by machine traffic and soil preconsolidation pressure. Such balance consists of the ability of soil to support loads without being compacted (DIAS JUNIOR et al., 2005). Under grazing areas, however, the same trend was not observed when comparing Bd in PA6 and PA2. This is likely due to a decline in vegetal coverage with the passing of years, reducing soil protection against direct impacts from animal trampling, raising the pressure exerted on the soil (PIRES et al., 2012).

Gas exchanges and water percolation in the soil are held within MaP portion. In all systems, this parameter was kept above critical point - aeration porosity $(<10 \%)$ (GRABLE; SIEMER, 1968), as shown in Table 3. Initially, the models of adjustment of data were studied to better understand potential changes in water retention capacity and resistance to penetration of the evaluated soils. We infer that the adjusted equations explained more than $80 \%$ of the variability for both water content and PR.

The magnitude of the model coefficients adjusted to the WRC and the CRP denotes a negative correlation of water content and $\mathrm{PR}$ with matric potential, and a positive one with $\mathrm{Bd}$. It could be observed due to a negative sign of $b$ and $e$ parameters; as well as a positive of $c$ and $f$, in each equation (Table 4). Tormena et al. (1998), Blainski et al. (2009) and Serafim et al. (2013) had also reported the same correlations. The PR reduction with increased $\Theta$ is due to a lubricating effect of water, which reduces soil particle cohesion (TORMENA et al., 2007; PETEAN et al., 2010). Yet the increase in $\mathrm{PR}$ with the rise of $\mathrm{Bd}$ values is related to the effect of soil compaction according to Vepraskas (1984), resulting in increased contact or friction between particles. The positive relationship of $\Theta$ with $\mathrm{Bd}$ and negative with $\psi$ could be attributed to increased soil density under all land uses and managements, reducing $\mathrm{MaP}$ and increasing $\mathrm{MiP}$ (Table 3). As consequence, water retention increases, but not necessarily its availability, which is in agreement with findings by Tormena et al. (1999) and Torres et al. (2014).

Figure 2 shows the LLWR estimated for all assessed conditions for all $\mathrm{Bd}$ values and depth ranges. The $\mathrm{CI}$ of $\mathrm{Bd}\left(\mathrm{CI}_{B d}\right)$ enabled predicting alterations undergone by all soil properties under all land uses and management systems, anticipating potential negative consequences for soil physical quality. In this sense, Serafim et al. (2013) suggested these indexes to be taken into consideration in farm planning, aiming to maintain physical quality of the soils.

In all land uses and management systems as well as cultivation times, the upper limit of LLWR in the Latossolo Amarelo was defined by $\Theta_{\mathrm{FC}}$ (Figure 2), indicating conservation of an appropriate aeration for a soil moisture at field capacity (FC). On the other hand, $\Theta_{\mathrm{PR}}$ set the lower limit of LLWR to Bd above $1.43 \mathrm{Mg} \mathrm{m}^{-3}$, thereby reducing water availability in PA2, PA6, NT3, NT6 and CT8. For values below $1.43 \mathrm{Mg} \mathrm{m}^{-3}$, the lower limit of LLWR was defined by $\Theta_{\text {PWP }}$, which is equivalent to the amount of available water (AW) at a ceiling limit, indicating better soil physical quality in NC, EU6, EU12 and CT2. 
Table 4. Equations for curves of soil water retention (WRC) and penetration resistance (PRC), wherein $\Theta$ is the

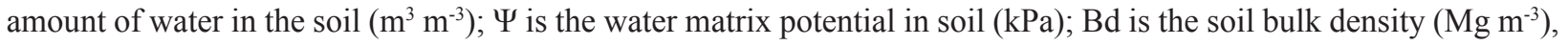
and PR is the soil penetration resistance (MPa).

\begin{tabular}{|c|c|c|c|c|}
\hline Management & $\mathrm{WRC}^{(1)}$ & $\mathrm{R}^{2}$ & $\mathrm{PRC}^{(2)}$ & $\mathrm{R}^{2}$ \\
\hline General & $\Theta=\operatorname{Exp}(-2.317+0.4146 \mathrm{Bd}) \Psi^{-0.1190}$ & $0.86^{* *}$ & $\mathrm{PR}=0.0027 \Theta^{-1.5274} \mathrm{Bd}^{9.5637}$ & $0.88 * *$ \\
\hline \multicolumn{5}{|c|}{$0.00-0.10 \mathrm{~m}$} \\
\hline $\mathrm{NC}$ & $\Theta=\operatorname{Exp}(-1.8498+0.1896 \mathrm{Bd}) \Psi^{-0.1060}$ & $0.89 * *$ & $\mathrm{PR}=0.0331 \Theta^{-1.7134} \mathrm{Bd}^{2.0165}$ & $0.86^{* *}$ \\
\hline EU6 & $\Theta=\operatorname{Exp}(-3.7100+1.4172 \mathrm{Bd}) \Psi^{-0.1210}$ & $0.90 * *$ & $\mathrm{PR}=0.0160 \Theta^{-1.0561} \mathrm{Bd}^{4.7738}$ & $0.82 * *$ \\
\hline EU12 & $\Theta=\operatorname{Exp}\left(-2.6139+0.5266 \mathrm{Bd}^{\prime} \Psi^{-0.1678}\right.$ & $0.97 * *$ & $\mathrm{PR}=0.0150 \Theta^{-1.6154} \mathrm{Bd}^{3.5001}$ & $0.89 * *$ \\
\hline PA2 & $\Theta=\operatorname{Exp}(-8.3645+4.6197 \mathrm{Bd}) \Psi^{-0.1015}$ & $0.95 * *$ & $\mathrm{PR}=0.0001 \Theta^{-1.8547} \mathrm{Bd}^{21.3010}$ & $0.96^{* *}$ \\
\hline PA6 & $\Theta=\operatorname{Exp}(-3.2158+1.0128 \mathrm{Bd}) \Psi^{-0.1086}$ & $0.95 * *$ & $\mathrm{PR}=0.0034 \Theta^{-2.0515} \mathrm{Bd}^{6.7138}$ & $0.98 * *$ \\
\hline $\mathrm{CT} 2$ & $\Theta=\operatorname{Exp}(-2.4262+0.5179 \mathrm{Bd}) \Psi^{-0.1172}$ & $0.96 * *$ & $\mathrm{PR}=0.0013 \Theta^{-2.0461} \mathrm{Bd}^{8.9320}$ & $0.97 * *$ \\
\hline CT8 & $\Theta=\operatorname{Exp}(-4.1008+1.6570 \mathrm{Bd}) \Psi^{-0.1228}$ & $0.92 * *$ & $\mathrm{PR}=0.0017 \Theta^{-1.9352} \mathrm{Bd}^{7.0638}$ & $0.99 * *$ \\
\hline NT3 & $\Theta=\operatorname{Exp}(-2.7325+0.7191 \mathrm{Bd}) \Psi^{-0.1388}$ & $0.96 * *$ & $\mathrm{PR}=0.0003 \Theta^{-1.5205} \mathrm{Bd}^{14.3136}$ & $0.80 * *$ \\
\hline NT6 & $\Theta=\operatorname{Exp}(-3.4820+1.2590 \mathrm{Bd}) \Psi^{-0.0955}$ & $0.87 * *$ & $\mathrm{PR}=0.0012 \Theta^{-1.9713} \mathrm{Bd}^{9.7582}$ & $0.84 * *$ \\
\hline \multicolumn{5}{|c|}{$0.10-0.20 \mathrm{~m}$} \\
\hline $\mathrm{NC}$ & $\Theta=\operatorname{Exp}(-1.7263+0.0115 \mathrm{Bd}) \Psi^{-0.1289}$ & $0.97 * *$ & $\mathrm{PR}=0.0238 \Theta^{-1.8573} \mathrm{Bd}^{2.2676}$ & $0.93 * *$ \\
\hline EU6 & $\Theta=\operatorname{Exp}(-2.8402+0.6830 \mathrm{Bd}) \Psi^{-0.1597}$ & $0.98 * *$ & $\mathrm{PR}=0.0023 \Theta^{-1.9478} \mathrm{Bd}^{5.9564}$ & $0.89 * *$ \\
\hline EU12 & $\Theta=\operatorname{Exp}(-2.1277+0.1482 \mathrm{Bd}) \Psi^{-0.1720}$ & $0.99 * *$ & $\mathrm{PR}=0.0013 \Theta^{-1.6790} \mathrm{Bd}^{9.95911}$ & $0.91 * *$ \\
\hline PA2 & $\Theta=\operatorname{Exp}(-2.2207+0.3904 \mathrm{Bd}) \Psi^{-0.1155}$ & $0.94 * *$ & $\mathrm{PR}=0.0001 \Theta^{-2.3793} \mathrm{Bd}^{18.4094}$ & $0.92 * *$ \\
\hline PA6 & $\Theta=\operatorname{Exp}(-2.6307+0.6665 \mathrm{Bd}) \Psi^{-0.1259}$ & $0.96 * *$ & $\mathrm{PR}=0.0027 \Theta^{-1.2760} \mathrm{Bd}^{10.3297}$ & $0.88 * *$ \\
\hline $\mathrm{CT} 2$ & $\Theta=\operatorname{Exp}(-2.4262+0.5179 \mathrm{Bd}) \Psi^{-0.1172}$ & $0.96 * *$ & $\mathrm{PR}=0.0013 \Theta^{-2.0461} \mathrm{Bd}^{8.9320}$ & $0.97 * *$ \\
\hline CT8 & $\Theta=\operatorname{Exp}(-2.2703+0.2847 \mathrm{Bd}) \Psi^{-0.1131}$ & $0.95 * *$ & $\mathrm{PR}=0.0004 \Theta^{-1.9629} \mathrm{Bd}^{11.5205}$ & $0.82 * *$ \\
\hline NT3 & $\Theta=\operatorname{Exp}(-2.7755+0.7493 \mathrm{Bd}) \Psi^{-0.1123}$ & $0.94 * *$ & $\mathrm{PR}=0.0016 \Theta^{-3.2498} \mathrm{Bd}^{3.6851}$ & $0.95 * *$ \\
\hline NT6 & $\Theta=\operatorname{Exp}(-1.9047+0.1812 \mathrm{Bd}) \Psi^{-0.1306}$ & $0.98 * *$ & $\mathrm{PR}=0.0048 \Theta^{-2.3766} \mathrm{Bd}^{5.2216}$ & $0.97 * *$ \\
\hline \multicolumn{5}{|c|}{$0.20-0.30 \mathrm{~m}$} \\
\hline $\mathrm{NC}$ & $\Theta=\operatorname{Exp}(-2.4303+0.4902 \mathrm{Bd}) \Psi^{-0.1104}$ & $0.99 * *$ & $\mathrm{PR}=0.0058 \Theta^{-2.2205} \mathrm{Bd}^{4.3847}$ & $0.92 * *$ \\
\hline EU6 & $\Theta=\operatorname{Exp}(-3.0715+0.7525 \mathrm{Bd}) \Psi^{-0.1756}$ & $0.95 * *$ & $\mathrm{PR}=0.0088 \Theta^{-1.6339} \mathrm{Bd}^{4.5469}$ & $0.95 * *$ \\
\hline EU12 & $\Theta=\operatorname{Exp}(-3.0103+0.7493 \mathrm{Bd}) \Psi^{-0.1564}$ & $0.98 * *$ & $\mathrm{PR}=0.0165 \Theta^{-1.6848} \mathrm{Bd}^{3.6434}$ & $0.90 * *$ \\
\hline PA2 & $\Theta=\operatorname{Exp}(-3.3403+1.0938 \mathrm{Bd}) \Psi^{-0.1015}$ & $0.95^{* *}$ & $\mathrm{PR}=0.0001 \Theta^{-3.1825} \mathrm{Bd}^{10.579}$ & $0.89 * *$ \\
\hline PA6 & $\Theta=\operatorname{Exp}(-3.3049+1.0959 \mathrm{Bd}) \Psi^{-0.0971}$ & $0.96^{* *}$ & $\mathrm{PR}=0.0001 \Theta^{-2.1866} \mathrm{Bd}^{17.5474}$ & $0.84 * *$ \\
\hline CT2 & $\Theta=\operatorname{Exp}(-2.9788+0.8536 \mathrm{Bd}) \Psi^{-0.1048}$ & $0.97 * *$ & $\mathrm{PR}=0.0004 \Theta^{-2.3189} \mathrm{Bd}^{10.4241}$ & $0.91 * *$ \\
\hline СТ8 & $\Theta=\operatorname{Exp}(-4.8008+1.9214 \mathrm{Bd}) \Psi^{-0.1017}$ & $0.80 * *$ & $\mathrm{PR}=0.0009 \Theta^{-2.2538} \mathrm{Bd}^{8.4957}$ & $0.90 * *$ \\
\hline NT3 & $\Theta=\operatorname{Exp}(-2.6113+0.5963 \mathrm{Bd}) \Psi^{-0.1123}$ & $0.97 * *$ & $\mathrm{PR}=0.0005 \Theta^{-2.7975} \mathrm{Bd}^{7.7718}$ & $0.85 * *$ \\
\hline NT6 & $\Theta=\operatorname{Exp}(-2.2304+0.4058 \mathrm{Bd}) \Psi^{-0.1126}$ & $0.97 * *$ & $\mathrm{PR}=0.0242 \Theta^{-1.8805} \mathrm{Bd}^{3.7728}$ & $0.83 * *$ \\
\hline \multicolumn{5}{|c|}{$0.30-0.40 \mathrm{~m}$} \\
\hline $\mathrm{NC}$ & $\Theta=\operatorname{Exp}(-1.5474+0.0824 \mathrm{Bd}) \Psi^{-0.1002}$ & $0.97 * *$ & $\mathrm{PR}=0.0022 \Theta^{-3.1635} \mathrm{Bd}^{2.5768}$ & $0.97 * *$ \\
\hline EU6 & $\Theta=\operatorname{Exp}(-3.9790+1.4742 \mathrm{Bd}) \Psi^{-0.1198}$ & $0.80 * *$ & $\mathrm{PR}=0.0004 \Theta^{-1.9121} \mathrm{Bd}^{10.6029}$ & $0.89 * *$ \\
\hline EU12 & $\Theta=\operatorname{Exp}(-4.2396+1.5444 \mathrm{Bd}) \Psi^{-0.1337}$ & $0.98 * *$ & $\mathrm{PR}=0.0001 \Theta^{-3.0872} \mathrm{Bd}^{10.8440}$ & $0.99 * *$ \\
\hline PA2 & $\Theta=\operatorname{Exp}(-2.4785+0.5303 \mathrm{Bd}) \Psi^{-0.1241}$ & $0.99 * *$ & $\mathrm{PR}=0.0003 \Theta^{-3.4171} \mathrm{Bd}^{7.5904}$ & $0.86^{* *}$ \\
\hline PA6 & $\Theta=\operatorname{Exp}(-2.0230+0.2313 \mathrm{Bd}) \Psi^{-0.1099}$ & $0.96 * *$ & $\mathrm{PR}=0.0008 \Theta^{-3.8704} \mathrm{Bd}^{2.1616}$ & $0.93 * *$ \\
\hline $\mathrm{CT} 2$ & $\Theta=\operatorname{Exp}(-2.4418+0.5803 \mathrm{Bd}) \Psi^{-0.1042}$ & $0.96 * *$ & $\mathrm{PR}=0.0010 \Theta^{-2.4006} \mathrm{Bd}^{8.6215}$ & $0.97 * *$ \\
\hline CT8 & $\Theta=\operatorname{Exp}(-3.3169+0.9905 \mathrm{Bd}) \Psi^{-0.1030}$ & $0.96 * *$ & $\mathrm{PR}=0.0001 \Theta^{-3.1345} \mathrm{Bd}^{15.1276}$ & $0.95 * *$ \\
\hline NT3 & $\Theta=\operatorname{Exp}(-3.2008+1.0333 \mathrm{Bd}) \Psi^{-0.1034}$ & $0.95 * *$ & $\mathrm{PR}=0.0001 \Theta^{-3.3070} \mathrm{Bd}^{11.9047}$ & $0.93 * *$ \\
\hline NT6 & $\Theta=\operatorname{Exp}(-2.8088+0.7368 \mathrm{Bd}) \Psi^{-0.1202}$ & $0.99 * *$ & $\mathrm{PR}=0.0004 \Theta^{-2.7958} \mathrm{Bd}^{9.5948}$ & $0.98 * *$ \\
\hline
\end{tabular}

(1); (2) The coefficients of the models of water retention curve and soil penetration resistance were significant ( $\mathrm{p}<0.01)$ by the $\mathrm{F}$ test; ** $(\mathrm{p}<0.01),{ }^{n s}(\mathrm{p}>0.01)$. Soil managements: native Cerrado (NC); eucalyptus plantation of six years (EU6); eucalyptus plantation of twelve years (EU12); pasture of two years (PA2); pasture of six years (PA6); conventional tillage of two years (CT2); conventional tillage of eight years (CT8), no-till of three years (NT3), no-till of six years (NT6). 
Figure 2. Changes in water content $(\Theta)$ due to alterations in soil bulk density $(\mathrm{Bb})$ for the studied cases at a depth range of 0.0 to $0.40 \mathrm{~m}$, in an average texture Latossolo Amarelo Distrófico típico caulinítico (Oxisol). Values for the critical levels of field capacity $\left(\Theta_{\mathrm{FC}}\right)$, permanent wilting point $\left(\Theta_{\mathrm{PWP}}\right)$, aeration porosity of $0.10 \mathrm{~m}^{3} \mathrm{~m}^{-3}\left(\Theta_{\mathrm{AP}}\right)$ and soil penetration resistance of $2.0 \mathrm{MPa}\left(\Theta_{\mathrm{PR}}\right) . \mathrm{CI}_{B b}$ : Confidence interval for bulk density at each soil management: native Cerrado (NC); eucalyptus plantation of six years (EU6); eucalyptus plantation of twelve years (EU12); pasture of two years (PA2); pasture of six years (PA6); conventional tillage of two years (CT2); conventional tillage of eight years (CT8), no-till of three years (NT3), no-till of six years (NT6).

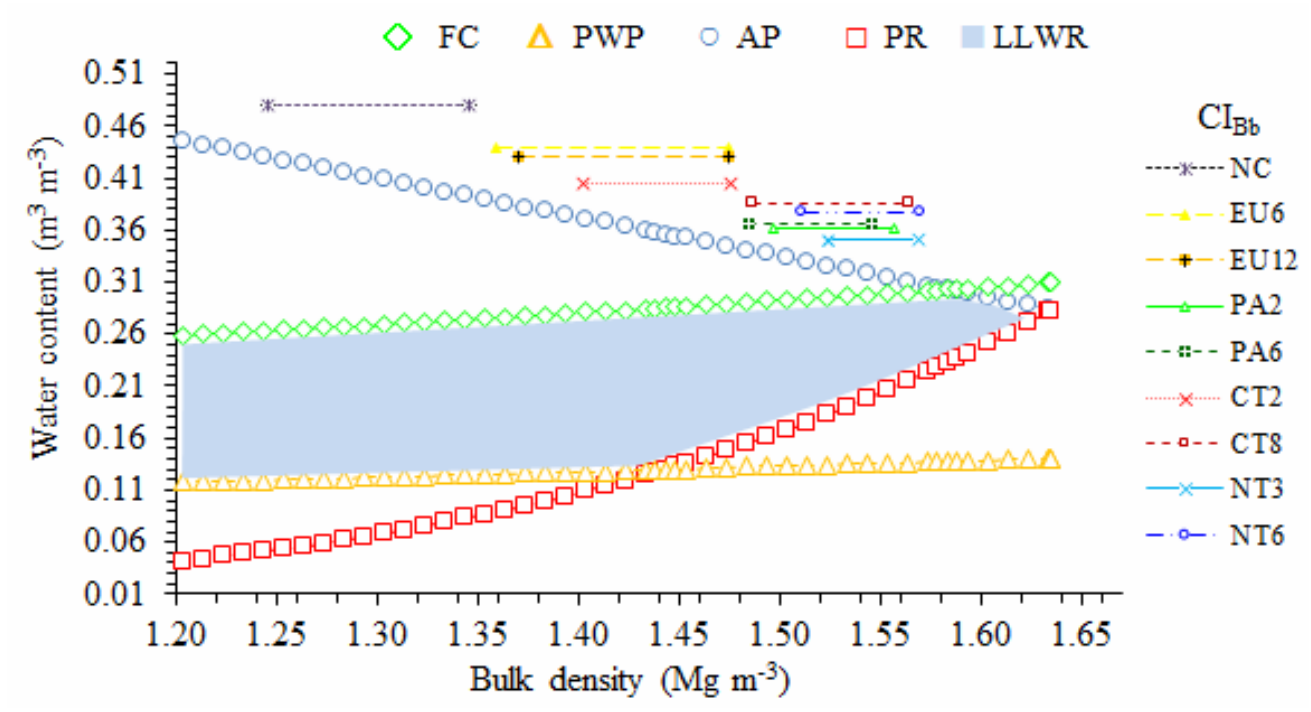

Considering the $\mathrm{CI}_{B d}$ values, $\mathrm{NC}$ conversion into eucalyptus areas (EU6 and EU12) as well as conventional tillage for two years (CT2) did not cause significant changes in soil due to the similarity of these systems with natural conditions (Figure 2). Apparently, the lowest soil degradation in CT2 is due to the short time. This statement is supported by Fontenele et al. (2009), who concluded that soil density is higher in farm systems under no-till and conventional tillage, compared to areas recently cleared of a Latossolo Amarelo in southern Piauí state. The smallest $\mathrm{CI}_{B d}$ values for EU6 and EU12, in comparison to the other agricultural systems, may be related to the fact that these areas have not been deforested yet. Overall, the most significant impact on physical properties of soils under forests comes from vehicle traffic during mechanized operations, mainly harvesting as well as extraction of timber (DIAS JUNIOR et al., 2005).

No-till systems (NT3 and NT6), pastures (PA2 and PA6) and conventional tillage (CT8) were the ones that apparently have had soil structure mostly degraded (Table 3 and Figure 2). The high values of $\mathrm{CI}_{B d}$ for NT6 and NT3 may be associated with soil lack of disturbance, as well as traffic of agricultural machinery. According Richart et al. (2005), traffic is the main cause of soil compaction, which has been enhanced by agriculture modernization, with the increased weight of machinery and equipment besides high land use intensity.

Even though the present study evaluates physical quality of soil under different situations, Bd should be used with caution for not making errors when itemizing some systems, as well as not being the only parameter used as benchmark. Still, in view of the importance of organic matter in soil quality studies, in the specific case of this study, it is important to note that the only areas with evolution in organic carbon were PA6 and NT6 (Table 2), which shows the need to relate the physical quality of the soil with various parameters.

According Albuquerque et al. (2001), under pasture, degradation occurs due to animal 
trampling, what may cause drastic changes in soil physical conditions that eventually interfere with root development, maximize physical degradation, thereby jeopardizing plant growth (BETTERIDGE et al., 1999). In conventional tilling, e.g. in CT8, it is noteworthy mention that soil preparation was performed with harrow, which moves soil at short depths. However, after several consecutive years, a continuous use of such agricultural implement may have led to the formation of compacted layers in subsurface (Table 3), which would limit root growth and, consequently, crop yields (SILVA et al., 2000).

Figure 3 shows the relationships between LLWR and $\mathrm{Bd}$ under the different land uses, management systems and all evaluated depths. Through this, we can note that in $0.0-0.10-\mathrm{m}$ depth, the Bd value in which LLWR was 0 , i.e. soil critical density $\left(\mathrm{Bd}_{c}\right)$, was $1.61 \mathrm{Mg} \mathrm{m}^{-3}$ for $\mathrm{NC}, 1.88$ for EU6, 1.88 for EU12, 1.79 for PA2, 1.57 for PA6, 1.71 for CT2, 1.78 for CT8, 1.61 for NT3 and 1.65 for NT6. In the $0.10-0.20-\mathrm{m}$ depth, the $\mathrm{Bd}_{c}$ values were $1.68,1.86$, $1.70,1.85,1.64,1.63,1.67,1.81$ and $1.71 \mathrm{Mg} \mathrm{m}^{-3}$ for NC, EU6, EU12, PA2, PA6, CT2, CT8, NT3 and NT6, respectively. In the $0.20-0.30-\mathrm{m}$ depth, these values were $1.68,1.79,1.85,1.85,1.70,1.62,1.72$, 1.74 and $1.64 \mathrm{Mg} \mathrm{m}^{-3}$, respectively. And for 0.30 0.40 -m depth, they were $1.68,1.87,1.89,1.74,1.73$, $1.88,1.69,1.69$ and $1.70 \mathrm{Mg} \mathrm{m}^{-3}$, respectively for the listed above systems.

Figure 3. Least limiting water range (LLWR) as a function of bulk density $(\mathrm{Bb})$ for the depth ranges of $0-0.10 ; 0.10$ $0.20 ; 0.20-0.30$ and $0.30-0.40 \mathrm{~m}$ of a Latossolo Amarelo Distrófico típico caulinítico under different soil managements: native Cerrado (NC); eucalyptus plantation of six years (EU6); eucalyptus plantation of twelve years (EU12); pasture of two years (PA2); pasture of six years (PA6); conventional tillage of two years (CT2); conventional tillage of eight years (CT8), no-till of three years (NT3), no-till of six years (NT6).

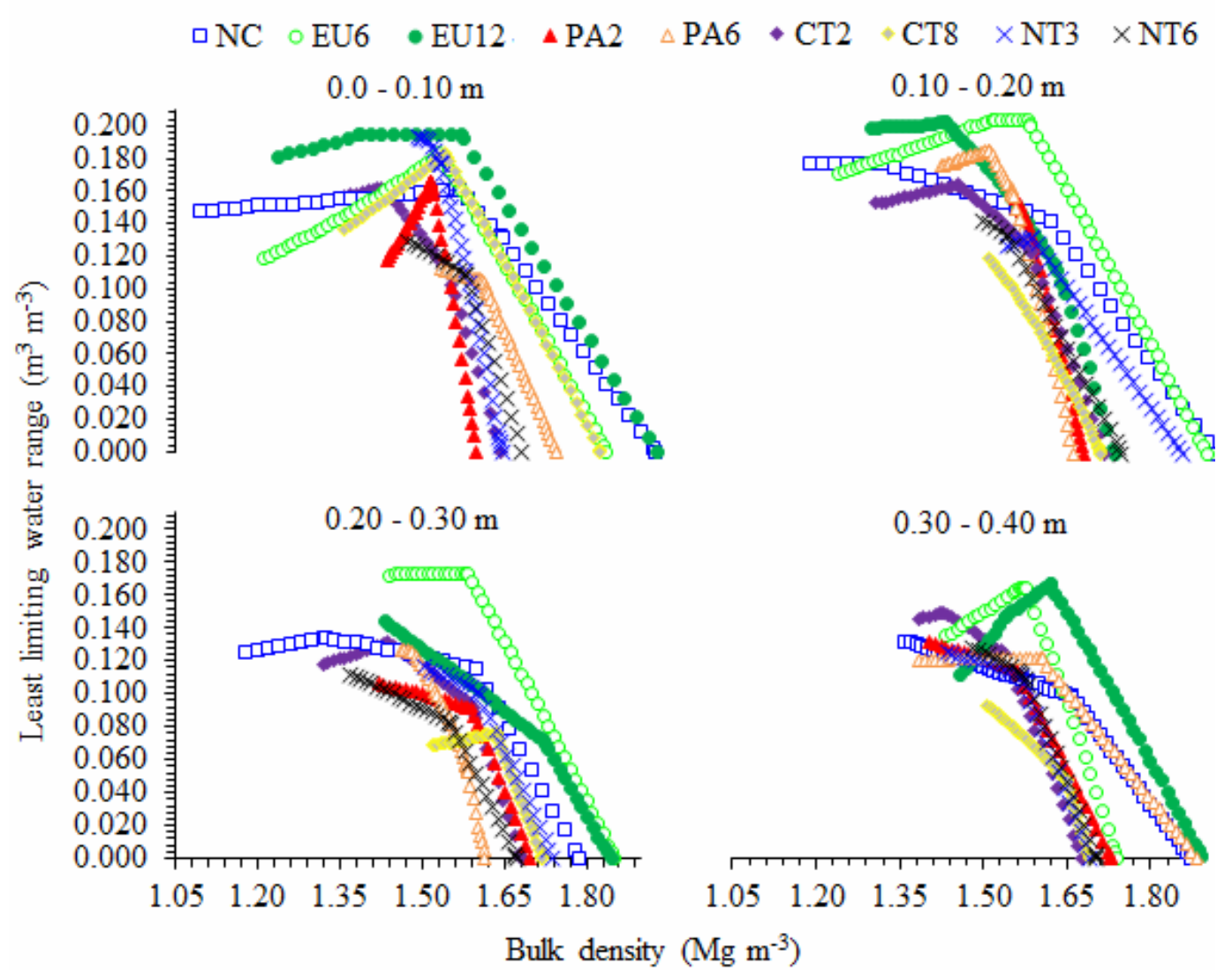


For the depth range of $0.0-0.10 \mathrm{~m}$, in CT2, EU6, EU12, PA2 and CT8, we observed that raises in Bd had positive influence on available water amount in the soil. Such fact can also be observed in subsurface, mainly under eucalyptus plantations, corroborating the findings of Tormena et al. (1998). Moreover, this influence evinces a gain in water retention inasmuch as $\mathrm{Bd}$ increases, which can be justified by $\mathrm{MaP}$ reduction and redistribution of pore sizes (Table 3 and Figure 3). Thus, LLWR was greater in the 0-0.10-m depth, and decreased for each depth range as seen in Figure 3. This fact has occurred because of a raise in $\mathrm{PR}$, which consisted of a limiting factor of LLWR (Table 3 and Figure 2). These findings corroborate those observed by Imhoff et al. (2001), Petean et al. (2010) and Fidalski et al. (2013).
Analyzing the correlation matrix of properties in a Latossolo Amarelo, we observed a positive correlation of LLWR with TP, MaP, AP and OC; conversely, for PR and Bd, it was negative (Table 5). Thus, it is clear that LLWR had improved relations with properties that are most likely to change by management system action. In this sense, Ramos et al. (2012) also found a positive correlation between LLWR and soil organic matter. This is justified since LLWR is directly affected by alterations in soil structure, which is favored by increasing contents of OC, which is an important agent in aggregate formation and stabilization (CASTRO FILHO et al., 1998; FONSECA et al., 2007).

Table 5. Correlation matrix between soil water-physical properties and organic carbon content of a Latossolo Amarelo Distrófico típico caulinítico (Oxisol), regardless of management and soil depth layer.

\begin{tabular}{|c|c|c|c|c|c|c|c|c|c|c|c|c|c|c|}
\hline & LLWR & TP & $\mathrm{MaP}$ & MiP & CS & FS & TS & $\mathrm{S}$ & C & OC & AP & PR & $\mathrm{Bd}$ & AW \\
\hline LLWR & 1 & $0.82 * *$ & $0.81^{* *}$ & $-0.36^{\text {ns }}$ & $-0.14^{\text {ns }}$ & $0.01^{\mathrm{ns}}$ & $-0.09^{\mathrm{ns}}$ & $0.20^{\text {ns }}$ & $0.51 *$ & $0.64 * *$ & $0.82 * *$ & $-0.63^{* *}$ & $-0.82 * *$ & $0.06^{\mathrm{ns}}$ \\
\hline $\mathrm{TP}$ & & 1 & $0.93 * *$ & $-0.28^{\mathrm{ns}}$ & $-0.15^{\mathrm{ns}}$ & $0.01^{\mathrm{ns}}$ & $-0.18^{\mathrm{ns}}$ & $0.09^{\text {ns }}$ & $0.48 * *$ & $0.58 * *$ & $0.97 * *$ & $-0.84 * *$ & $-0.97 * *$ & $-0.06^{\mathrm{ns}}$ \\
\hline $\mathrm{MaP}$ & & & 1 & $-0.62 * *$ & $-0.09^{\mathrm{ns}}$ & $0.01^{\mathrm{ns}}$ & $-0.06^{\mathrm{ns}}$ & $0.13^{\text {ns }}$ & $0.19^{\text {ns }}$ & $0.48^{*}$ & $0.94 * *$ & $-0.80 * *$ & $-0.94 * *$ & $-0.07^{\mathrm{ns}}$ \\
\hline MiP & & & & 1 & $-0.12^{\mathrm{ns}}$ & $0.05^{\text {ns }}$ & $-0.21^{\mathrm{ns}}$ & $-0.17^{\mathrm{ns}}$ & $0.54 *$ & $0.19^{\mathrm{ns}}$ & $0.38^{\text {ns }}$ & $0.40^{*}$ & $0.48 * *$ & $0.43^{*}$ \\
\hline CS & & & & & 1 & $-0.94 * *$ & $-0.02^{\mathrm{ns}}$ & $0.28^{\mathrm{ns}}$ & $0.20^{\text {ns }}$ & $-0.17^{\mathrm{ns}}$ & $-0.04^{\mathrm{ns}}$ & $0.10^{\text {ns }}$ & $0.04^{\mathrm{ns}}$ & $0.32^{\mathrm{ns}}$ \\
\hline FS & & & & & & 1 & $-0.16^{\mathrm{ns}}$ & $0.26^{\mathrm{ns}}$ & $-0.62 *$ & $0.01^{\mathrm{ns}}$ & $-0.09^{\mathrm{ns}}$ & $-0.05^{\mathrm{ns}}$ & $0.09^{\mathrm{ns}}$ & $0.52^{*}$ \\
\hline TS & & & & & & & 1 & $0.36^{\mathrm{ns}}$ & $-0.64 * *$ & $0.18^{\mathrm{ns}}$ & $-0.17^{\mathrm{ns}}$ & $0.05^{\mathrm{ns}}$ & $0.16^{\mathrm{ns}}$ & $0.08^{\text {ns }}$ \\
\hline $\mathrm{S}$ & & & & & & & & 1 & $0.00^{\text {ns }}$ & $0.16^{\mathrm{ns}}$ & $0.18^{\text {ns }}$ & $0.04^{\mathrm{ns}}$ & $-0.18^{\text {ns }}$ & $-0.38^{\mathrm{ns}}$ \\
\hline $\mathrm{C}$ & & & & & & & & & 1 & $0.53 * *$ & $0.43 *$ & $-0.11^{\mathrm{ns}}$ & $-0.33^{\text {ns }}$ & $0.13^{\mathrm{ns}}$ \\
\hline $\mathrm{OC}$ & & & & & & & & & & 1 & $0.56^{* *}$ & $-0.33^{\mathrm{ns}}$ & $-0.36^{\text {ns }}$ & $0.26^{\mathrm{ns}}$ \\
\hline $\mathrm{AP}$ & & & & & & & & & & & 1 & $-0.80 * *$ & $-0.98 * *$ & $-0.01^{\mathrm{ns}}$ \\
\hline PR & & & & & & & & & & & & 1 & $0.80 * *$ & $-0.03^{\mathrm{ns}}$ \\
\hline $\mathrm{Bd}$ & & & & & & & & & & & & & 1 & $0.01^{\mathrm{ns}}$ \\
\hline AW & & & & & & & & & & & & & & 1 \\
\hline
\end{tabular}

Table 5 displays a positive correlation among AW, MiP and FS. Such result might be connected to soil-pore continuity, seeing that elevated contents of FS within the soil particle size (Table 2) may contribute the deposition of this material into macropores, forming micropores that will reduce continuity. Some studies point out that certain particles as clay, silt and fine sand are carried through porous medium and laid on macropore surfaces, leading to clogging (DRIESE; McKAY, 2004; CEY et al., 2009), holding a larger amount of water within the soil at higher potentials (up to -0.06 $\mathrm{MPa}$ ), increasing as consequence water availability. 


\section{Conclusions}

The conversion of native Cerrado areas into conventional tillage of 2 years, eucalyptus plantation of six and twelve resulted in fewer changes of water-physical properties in a Latossolo Amarelo Distrófico típico caulinítico.

Longer-term conventional tillage promoted degradation of water-physical properties, as well as a reduction of organic carbon in the soil.

The conversion of native Cerrado areas into no-till system and grazing areas raised contents of organic carbon over time.

The correlation analysis highlighted the influence of organic carbon on the least limit water range of a Latossolo Amarelo Distrófico típico caulinítico, while available water has influence of the content of fine sand.

\section{Acknowledgments}

The authors thank to the PROCAD established between Federal University of Piauí (UFPI), and the Federal University of Lavras (UFLA) which provided the facilities of the Physics Laboratory and Soil Conservation and Water for this study. The Postgraduate Program in Soil and Plant Nutrition (PPSNP) the campus Teacher Cinobelina Elvas (CPCE / UFPI). To the CNPq and CAPES by the granting for postgraduate scholarship to first author and the owners of farms of the New Santa Rosa region by the logistical support.

\section{References}

AGUiAR, T. J. A.; MONTEIRO, M. S. L. Modelo agrícola e desenvolvimento sustentável: a ocupação do Cerrado Piauiense. Ambiente \& Sociedade, São Paulo, v. 8, n. 2, p. 1-18, 2005.

ALBUQUERQUE, J. A.; SANGOI, L.; ENDER, M. Efeito da integração lavoura pecuária nas propriedades físicas do solo e características da cultura do milho. Revista Brasileira de Ciência do Solo, Viçosa, MG, v. 25, n. 3, p. 717-723, 2001.
ARAÚJO, R.; GOEDERT, W. J.; LACERDA, M. P. C. Qualidade de um solo sob diferentes usos e sob cerrado nativo. Revista Brasileira de Ciência do Solo, Viçosa, MG, v. 31, n. 5, p. 1099-1108, 2007.

BERTOL， I.; ALBUQUERQUE, J. A.; LEITE, D.; AMARAL, A. J.; ZOLDAN JUNIOR, W. A. Propriedades físicas do solo sob preparo convencional e semeadura direta em rotação e sucessão de culturas, comparadas às do campo nativo. Revista Brasileira de Ciência do Solo, Viçosa, MG, v. 28, n. 1, p. 155-163, 2004.

BETTERIDGE, K.; MACKAY, A. D.; SHEPHERD, T. G.; BARKER, D. J.; BUDDING, P. J.; DEVANTIER, B. P.; COSTALL, D. A. Effect of cattle and sheep treading on surface configuration of a sedimentary hill soil. Australian Journal of Soil Research, Collingwood, v. 37, n. 4, p. 743-760, 1999.

BLAINSKI, E.; GONÇALVES, A. C. A.; TORMENA, C. A.; FOLEGATT I, M. V.; GUIMARÃES, R. M. L. Intervalo hídrico ótimo num Nitossolo Vermelho distroférrico irrigado. Revista Brasileira de Ciência do Solo, Viçosa, MG, v. 33, n. 2, p. 273-281, 2009.

CASTRO FILHO, C.; MUZILLI, O.; PODANOSCHI, A. L. Estabilidade dos agregados e sua relação com o teor de carbono orgânico em um Latossolo Roxo Distrófico, em função de sistemas de plantio, rotações de culturas e métodos de preparo das amostras. Revista Brasileira de Ciência do Solo, Viçosa, MG, v. 22, n. 3, p. 527-538, 1998.

CEY, E. E.; RUDOLPH, D. L.; PASSMORE, J. Influence of macroporosity on preferencial solute and colloid transport in unsaturated field soils. Journal of Contaminant Hydrology, Amsterdam, v. 107, n. 1-2, p. 45-57, 2009.

COMPANHIA NACIONAL DE ABASTECIMENTO - CONAB. $6^{\circ}$ Levantamento da produção de grãos Safra 2013/14. Brasília: CONAB, 2014. Disponível em: $<$ http://www.conab.gov.br>. Acesso em: 15 mar. 2014.

DIAS JUNIOR, M. S.; LEITE, F. P.; LASMAR JÚNIOR, E.; ARAÚJO JUNIOR, C. F. Traffic effects on the soil preconsolidation pressure due to eucalyptus harvest operations. Scientia Agricola, Piracicaba, v. 62, n. 3, p. 248-255, 2005.

DONAGEMA, G. K.; CAMPOS, D. V. B.; CALDERANO, S. B.; TEIXEIRA, W. G.; VIANA, J. H. M. Manual de métodos de análise de solos. Rio de Janeiro: Embrapa Solos, 2011. 230 p.

DRIESE, S. G.; McKAY, L. D. Epi-fluorescence micromorphology of saprolite reveals evidence for colloid retention in microscale pore systems. Geoderma, Amsterdam, v. 121, n. 1-2, p. 143-152, 2004. 
EMPRESA BRASILEIRA DE PESQUISA AGROPECUÁRIA - EMBRAPA. Sistema brasileiro de classificação de solos. 3. ed. Brasília: EMBRAPA, 2013. $353 \mathrm{p}$.

FIDALSKI, J.; TORMENA, C. A.; ALVES, S. J. Intervalo hídrico ótimo de um Latossolo Vermelho distrófico, após o primeiro período de Pastejo contínuo de brachiaria ruziziensis, em sistema Integração lavourapecuária. Revista Brasileira de Ciência do Solo, Viçosa, MG, v. 37, n. 3, p. 775-783, 2013.

FIGUEIREDO, C. C.; SANTOS, G. G.; PEREIRA, S.; NASCIMENTO, J. L.; ALVES JUNIOR, J. Propriedades físico-hídricas em Latossolo do Cerrado sob diferentes sistemas de manejo. Revista Brasileira de Engenharia Agrícola e Ambiental, Campina Grande, v. 13, n. 2, p. 146-151, 2009.

FONSECA, G. C.; CARNEIRO, M. A. C.; COSTA, A. R.; OLIVEIRA, G. C.; BALBINO, L. C. Atributos físicos, químicos e biológicos de Latossolo vermelho distrófico de cerrado sob duas rotações de cultura. Pesquisa Agropecuária Tropical, Goiânia, v. 37, n. 1, p. 22-30, 2007.

FONTENELE, W.; SALVIANO, A. A. C.; MOUSINHO, F. E. P. Atributos físicos de um Latossolo Amarelo sob sistemas de manejo no cerrado piauiense. Revista Ciência Agronômica, Fortaleza, v. 40, n. 2, p. 194-202, 2009.

GRABLE, A. R.; SIEMER, E. G. Effects of bulk density, aggregate size, and soil water suction on oxygen diffusion, redox potential and elongation of corns roots. Soil Science Society of America Journal Proceedings, Madison, v. 32, n. 2, p. 180-186, 1968.

GUIMARAES, R. M. L.; TORMENA, C. A.; BLAINSKI, E.; FIDALSKI, J. Intervalo hídrico ótimo para avaliação da degradação física do solo. Revista Brasileira de Ciência do Solo, Viçosa, MG, v. 37, n. 6, p. 1512-1521, 2013.

IMHOFF, S.; SILVA, A. P.; DIAS JUNIOR, M. S.; TORMENA, C. A. Quantificação das pressões críticas para o crescimento das plantas. Revista Brasileira de Ciência do Solo, Viçosa, MG, v. 25, n. 1, p. 11-18, 2001.

INSTITUTO BRASILEIRO DE GEOGRAFIA E ESTATÍSTICA - IBGE. Censo agropecuário 2006. Rio de Janeiro: IBGE, 2006. Disponível em: <http://biblioteca. ibge.gov.br/index.php/bibliotecacatalogo?view= detalhes\&id=749>. Acesso em: 25 mar. 2013.

Índice de desenvolvimento humano municipal de 2013. Rio de Janeiro: IBGE, 2013. Disponível em: $<$ http:// www.ibge.gov.br/estadosat/temas.php?sigla=pi\&tema $=\mathrm{idhm}>$. Acesso em: 15 set. 2015.
Manual técnico de pedologia. Coordenação de Recursos Naturais e Estudos Ambientais. 2. ed. Rio de Janeiro: IBGE, 2007. 323 p. (Manuais Técnicos em Geociências, 4).

LEÃO, T. P.; SILVA, A. P. da; MACEDO, M. C. M.; IMHOFF, S.; EUCLIDES, V. P. B. Least limiting water range: a potential indicator of changes in near-surface soil physical quality after the conversion of Brazilian Savanna into pasture. Soil and Tillage Research, Amsterdam, v. 88, n. 1, p. 279-285, 2006.

LETEY, J. Relationship between soil physical properties and crop productions. Advances in Soil Science, New York, v. 1, n. 1, p. 277-294, 1985.

LIMA, V. M. P.; OLIVEIRA, G. C.; SERAFIM, N. E.; CURI, N.; EVANGELISTA, A. R. Intervalo hídrico ótimo como indicador de melhoria da qualidade estrutural de Latossolo degradado. Revista Brasileira de Ciência do Solo, Viçosa, MG, v. 36, n. 1, p. 71-78, 2012.

MACHADO, L. V.; RANGEL, O. J. P.; MENDONÇA, E. S.; MACHADO, R. V.; FERRARI, J. L. Fertilidade e compartimentos da matéria orgânica do solo sob diferentes sistemas de manejo. Coffee Science, Lavras, v. 9, n. 3, p. 289-299, 2014.

MELlO, C. R.; OLIVEIRA, G. C.; RESCK, D. V. S.; LIMA, J. M.; DIAS JÚNIOR, M. S. Estimativa da capacidade de campo baseada no ponto de inflexão da curva característica. Ciência e Agrotecnologia, Lavras, v. 26, n. 4, p. 836-841, 2002.

MENDES, F. G.; MELLONI, E. G. P.; MELLONI, R. Aplicação de atributos físicos do solo no estudo da qualidade de áreas impactadas, em Itajubá - MG. Cerne, Lavras, v. 12, n. 3, p. 211-220, 2006.

OLIVEIRA, G. C.; DIAS JUNIOR, M. S.; CURI, N.; RESCK, D. V. S. Caracterização química e físico-hídrica de um Latossolo Vermelho após 20 anos de manejo e cultivo do solo. Revista Brasileira de Ciência do Solo, Viçosa, MG, v. 28, n. 2, p. 335-344, 2004.

PETEAN, L. P.; TORMENA, C. A.; ALVES, S. J. Intervalo hídrico ótimo de um latossolo vermelho distroférrico sob plantio direto em sistema de integração lavoura-pecuária. Revista Brasileira de Ciência do Solo, Viçosa, MG, v. 34, n. 5, p. 1515-1526, 2010.

PIRES, B. S.; DIAS JUNIOR, M. S.; ROCHA, W. W.; ARAUJO JUNIOR, C. F.; CARVALHO, R. C. R. Modelos de capacidade de suporte de carga de um Latossolo Vermelho-amarelo sob diferentes usos e manejos. Revista Brasileira de Ciência do Solo, Viçosa, MG, v. 36, n. 2, p. 635-642, 2012. 
PRAGANA, R. B.; RIBEIRO, M. R.; NÓBREGA, J. C. A.; RIBEIRO FILHO, M. R.; COSTA, J. A. Qualidade física de Latossolos amarelos sob plantio direto na região do Cerrado piauiense. Revista Brasileira de Ciência do Solo, Viçosa, MG, v. 36, n. 5, p. 1591-1600, 2012.

R DEVELOPMENT CORE TEAM - RDCT. R: a language and environment statistical computing. Vienna: R Foundation for Statistical Computing, 2015.

RAMOS, F. T.; MAIA, J. C. S.; ROQUE, M. W.; SERAFIM, M. E. S.; AZEVEDO, E. C.; RAMOS, D. T. Intervalo hídrico ótimo de um Latossolo Vermelho distrófico sob cerrado nativo e cultivo mínimo com soja. Revista Brasileira de Ciências Agrárias, Belém, v. 55, n. 2, p. 124-133, 2012.

RESENDE, M.; BAHIA, F. A. F. C.; BRAGA, J. M. Mineralogia da argila de Latossolos estimada por alocação a partir do teor total de óxidos do ataque sulfúrico. Revista Brasileira de Ciência do Solo, Viçosa, MG, v. 11, n. 1, p. 17-23, 1987.

RICHART, A.; TAVARES FILHO, J.; BRITO, O. R.; LLANILLO, R. F.; FERREIRA, R. Compactação do solo: causas e efeitos. Semina: Ciências Agrárias, Londrina, v. 26, n. 3, p. 321-344, 2005.

SERAFIM, M. E.; OLIVEIRA, G. C.; VITORINO, A. C. T.; SILVA, B. M.; CARDUCCI, C. E. Qualidade física e intervalo hídrico ótimo em Latossolo e Cambissolo, cultivados com cafeeiro, sob manejo conservacionista do solo. Revista Brasileira de Ciência do Solo, Viçosa, MG, v. 37, n. 3, p. 733-742, 2013.

SEVERIANO, E. C.; OLIVEIRA, G. C.; DIAS JÚNIOR, M. S.; COSTA, K. A. P.; SILVA, F. G.; FERREIRA FILHO, S. M. Structural changes in Latosols representative of the Cerrado Region: I - Relationships between soil physical attributes and least limiting water range. Revista Brasileira de Ciência do Solo, Viçosa, MG, v. 35, n. 3, p. 773-782, 2011.

SILVA, A. P.; KAY, B. D.; PERFECT, E. Characterization of the least limiting water range. Soil Science Society of American Journal, Madison, v. 58, n. 6, p. 1775-1781, 1994.

SILVA, B. M.; OLIVEIRA, G. C.; SERAFIM, M. E.; SILVA, E. A.; FERREIRA, M. M.; NORTON, L. D.; CURI, N. Critical soil moisture range for a coffee crop in an oxidic Latosol as affected by soil management. Soil and Tillage Research, Amsterdam, v. 154, n. 1, p. 103113, 2015a.
SILVA, R. F.; GUIMARÃES, M. F.; AQUINO, A. M.; MERCANTE, F. M. Análise conjunta de atributos físicos e biológicos do solo sob sistema de integração lavourapecuária. Pesquisa Agropecuária Brasileira, Brasília, v. 46, n. 10, p. 1277-1283, 2011.

SILVA, R. F.; PACHECO, L. P.; SOARES, L. S.; FONSECA, W. L.; OLIVEIRA, J. B. S.; SANTOS, A. $\mathrm{S}$. Growth suppression of sandspur grass by cover crops. Pesquisa Agropecuária Tropical, Goiânia, v. 45, n. 3, p. 319-325, 2015b.

SILVA, V. R.; REICHERT, J. M.; REINERT, D. J. Susceptibilidade à compactação de um Latossolo Vermelho-Escuro e de um Podzólico Vermelho-Amarelo. Revista Brasileira de Ciência do Solo, Viçosa, MG, v. 4, n. 2, p. 239-249, 2000.

SOUSA, F. M.; PORTELA, G. L. F.; LIMA, M. G.; SOUSA, M. Zoneamento agroclimático da cultura da goiabeira no estado do Piauí, Brasil. Agropecuária Científica no Semi-Árido, Campina Grande, v. 9, n. 3, p. 81-86, 2013.

TAYLOR, H. M.; ROBERSON, G. M.; PARKER JUNIOR, J. J. Soil strength-root penetration relations to medium to coarsetextured soil materials. Soil Science, Baltimore, v. 102, n. 1, p. 18-22, 1966.

TORMENA, C. A.; ARAUJO, M. A.; FIDALSKI, J.; COSTA, M. J. Variação temporal do intervalo hídrico ótimo de um Latossolo Vermelho distroférrico sob sistemas de plantio direto. Revista Brasileira de Ciência do Solo, Viçosa, MG, v. 31, n. 2, p. 211-19, 2007.

TORMENA, C. A.; SILVA, A. P.; LIBARDI, P. L. Caracterização do intervalo hídrico ótimo de um Latossolo Roxo sob plantio direto. Revista Brasileira de Ciência do Solo, Viçosa, MG, v. 22, n. 2, p. 573-581, 1998.

Soil physical quality of a Brazilian Oxisol under two tillage systems using the least limiting water range approach. Soil Tillage Research, Amsterdam, v. 52, n. 1, p. 223-232, 1999.

TORRES, L. C.; BARROS, K. R. M.; LIMA, H. V. Alterações na qualidade física de um Latossolo amarelo sob pastagem. Acta Amazonica, Manaus, v. 44, n. 4, p. 419-426, 2014.

VEPRASKAS, M. J. Cone index of loamy sands as influenced by pore size distribution and effective stress. Soil Science Society of America Journa, Madison, v. 48, n. 6, p. 1220-1225, 1984. 